\title{
Erratum: Nasonova, S. et al. Linking Regional Winter Sea Ice Thickness and Surface Roughness to Spring Melt Pond Fraction on Landfast Arctic Sea Ice. Remote Sens. 2018, 10, 37
}

\author{
Sasha Nasonova ${ }^{1, *(1)}$, Randall K. Scharien ${ }^{1}$ (1) , Christian Haas ${ }^{2}$ and Stephen E. L. Howell ${ }^{3}$ (i) \\ 1 Department of Geography, University of Victoria, 3800 Finnerty Road, Victoria, BC V8P 5C2, Canada; \\ randy@uvic.ca \\ 2 Department of Earth and Space Sciences and Engineering, York University, 4700 Keele Street, \\ Toronto, ON M3J 1P3, Canada; haasc@yorku.ca \\ 3 Climate Research Division, Environment and Climate Change Canada, 4905 Dufferin Street, \\ Toronto, ON M3H 5T4, Canada; stephen.howell@canada.ca \\ * Correspondence: nasonova@uvic.ca; Tel.: +1-250-580-0027
}

After publication of the research paper [1], the authors wish to make the following correction. In Figures 7, 9, 11, 12, the legend depicted first-year ice (FYI) in red, and multiyear ice (MYI) in blue. The legend should have been reversed with FYI shown in blue and MYI in red. Both original and corrected versions of Figures 7, 9, 11, and 12 are given below.

Original Figure 7:
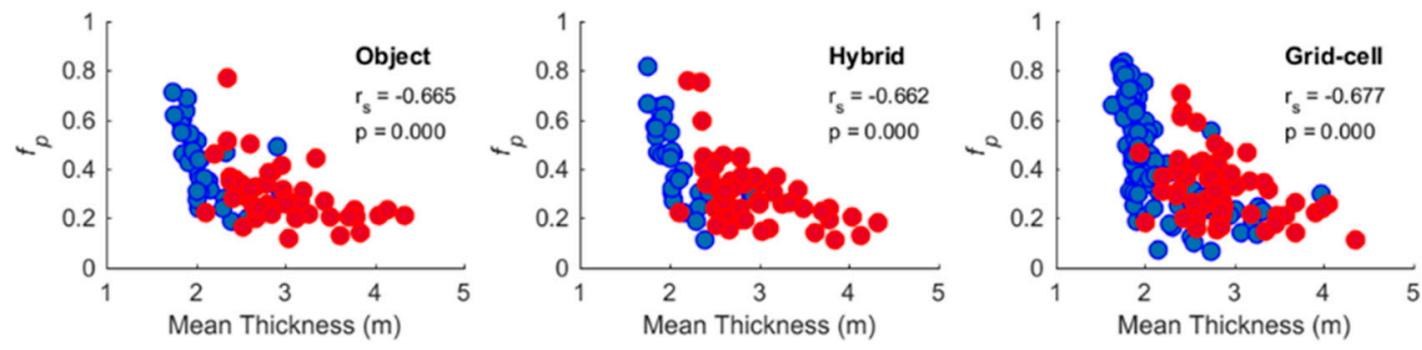

Figure 7. Scatter plots of $f_{p}$ as a function of mean thickness at the medium scale using object (left), hybrid object (middle) and $240 \mathrm{~m}$ grid-cell (right) aggregation approaches. Spearman correlation coefficients $\left(\mathrm{r}_{\mathrm{s}}\right)$ and corresponding $p$-values are shown for pooled FYI and MYI data. 
Corrected Figure 7:
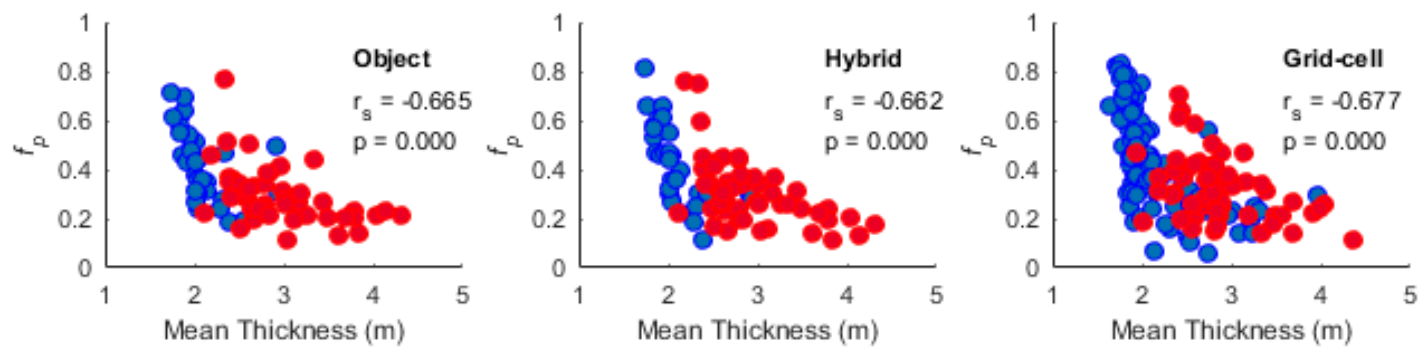

Figure 7. Scatter plots of $f_{p}$ as a function of mean thickness at the medium scale using object (left), hybrid object (middle) and $240 \mathrm{~m}$ grid-cell (right) aggregation approaches. Spearman correlation coefficients $\left(\mathrm{r}_{\mathrm{s}}\right)$ and corresponding $p$-values are shown for pooled FYI and MYI data.

Original Figure 9:
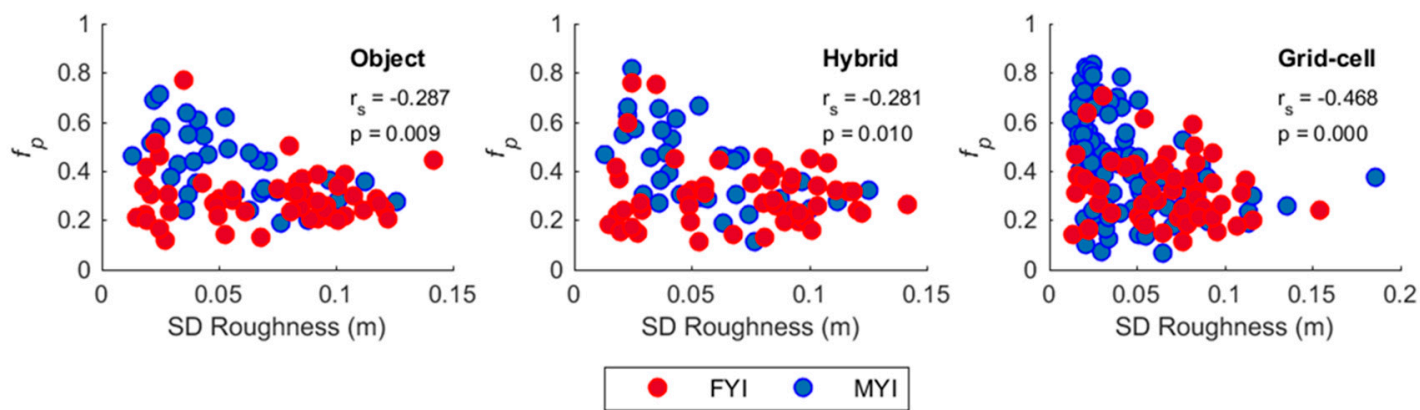

Figure 9. Scatter plots of $f_{p}$ as a function of standard deviation of roughness at the medium scale using object (left), hybrid object (middle) and $240 \mathrm{~m}$ grid-cell (right) aggregation approaches. Spearman correlation coefficients $\left(r_{s}\right)$ and corresponding $p$-values are shown for pooled FYI and MYI data.

Corrected Figure 9:
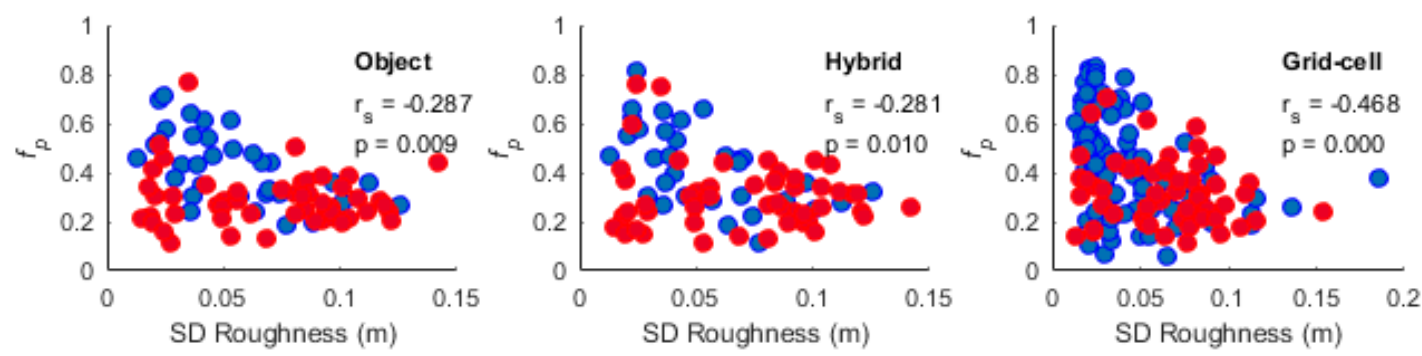

- FYI $\bigcirc \mathrm{MYI}$

Figure 9. Scatter plots of $f_{p}$ as a function of standard deviation of roughness at the medium scale using object (left), hybrid object (middle) and $240 \mathrm{~m}$ grid-cell (right) aggregation approaches. Spearman correlation coefficients $\left(\mathrm{r}_{\mathrm{s}}\right)$ and corresponding $p$-values are shown for pooled FYI and MYI data. 
Original Figure 11:
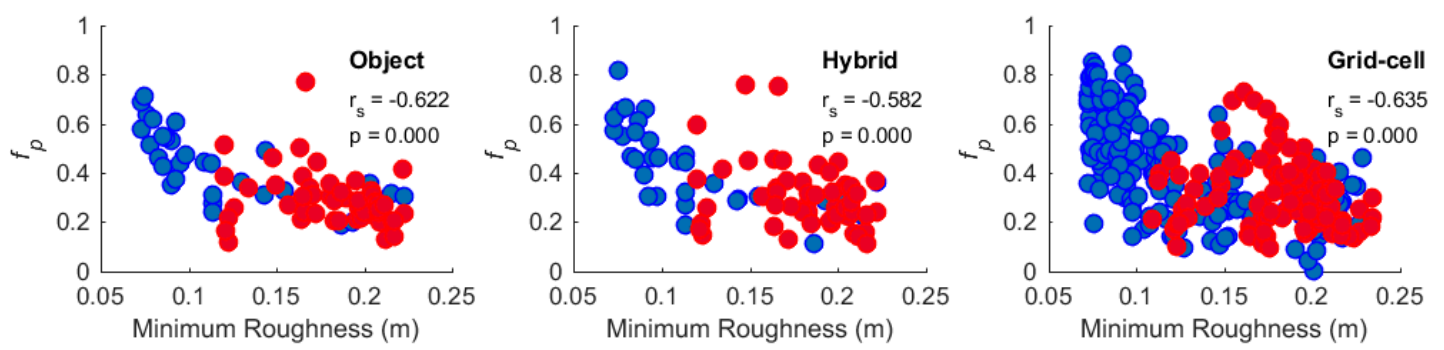

Figure 11. Scatter plots of $f_{p}$ as a function of smoothed minimum surface roughness at the medium scale using object (left), hybrid object (middle) and $240 \mathrm{~m}$ grid-cell (right) aggregation approaches. Spearman correlation coefficients $\left(\mathrm{r}_{\mathrm{s}}\right)$ and corresponding $p$-values are shown for pooled FYI and MYI data.

Corrected Figure 11:
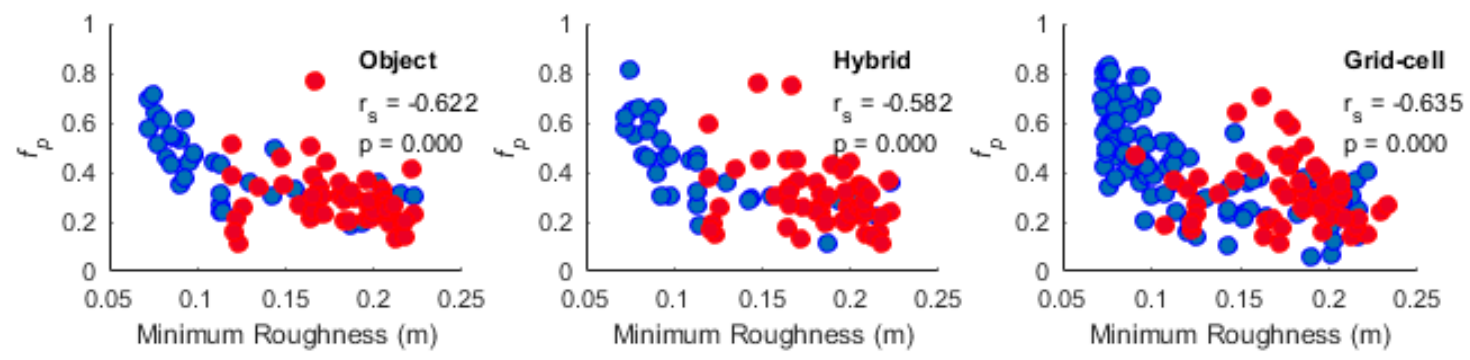

Figure 11. Scatter plots of $f_{p}$ as a function of smoothed minimum surface roughness at the medium scale using object (left), hybrid object (middle) and $240 \mathrm{~m}$ grid-cell (right) aggregation approaches. Spearman correlation coefficients $\left(\mathrm{r}_{\mathrm{s}}\right)$ and corresponding $p$-values are shown for pooled FYI and MYI data.

Original Figure 12:
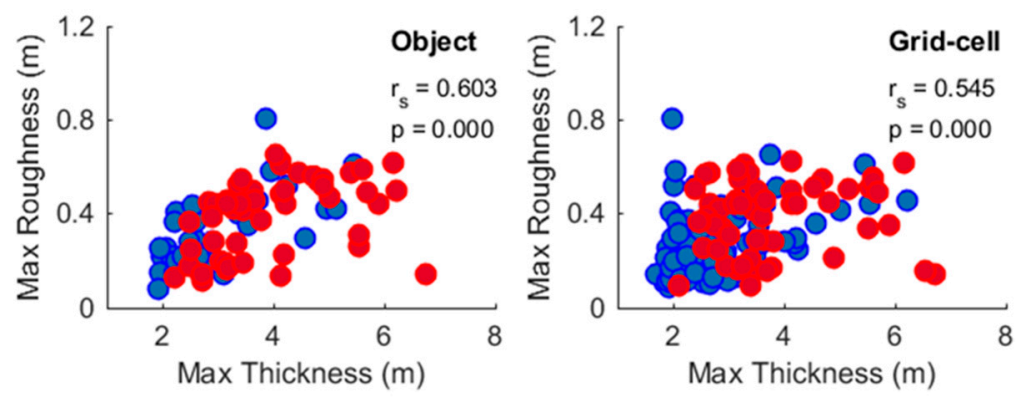

- FYI $\bigcirc$ MYI

Figure 12. Scatter plots of maximum roughness as a function of maximum thickness at the medium scale using object (left) and $240 \mathrm{~m}$ grid-cell (right) aggregation approaches. Spearman correlation coefficients $\left(\mathrm{r}_{\mathrm{s}}\right)$ and corresponding $p$-values are shown for pooled FYI and MYI data. 
Corrected Figure 12:
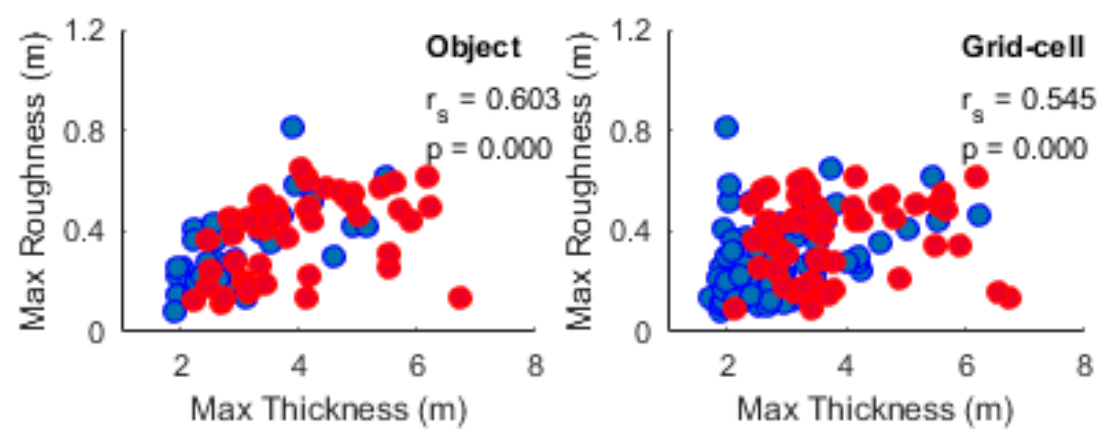

$\mathrm{FYI} \bullet \mathrm{MYI}$

Figure 12. Scatter plots of maximum roughness as a function of maximum thickness at the medium scale using object (left) and $240 \mathrm{~m}$ grid-cell (right) aggregation approaches. Spearman correlation coefficients $\left(\mathrm{r}_{\mathrm{s}}\right)$ and corresponding $p$-values are shown for pooled FYI and MYI data.

The blue points correspond to first-year ice (FYI) and red points to multiyear (MYI); however, a typo was made in the legends. This correction will not change the results or any statements in the paper. The authors apologize for any inconvenience caused for readers.

Conflicts of Interest: The authors declare no conflicts of interest.

\section{Reference}

1. Nasonova, S.; Scharien, R.K.; Haas, C.; Howell, S.E.L. Linking Regional Winter Sea Ice Thickness and Surface Roughness to Spring Melt Pond Fraction on Landfast Arctic Sea Ice. Remote Sens. 2018, 10, 37. [CrossRef] 